\title{
Azolla (CARoliniana): An Aquatic ENERGY CROP FOR REMEDIATION OF EUTROPHIC ECOSYSTEMS WITH PROSPECT OF Biofuel Production in BANGLAdesh
}

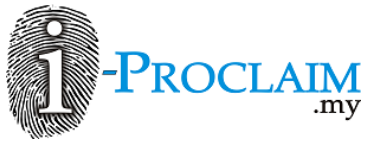

Asia Pac. j. energy environ.

\section{Kamrun Nahar}

Associate Professor, Department of Environmental Science and Management, North South University, Dhaka, BANGLADESH

*Email for Correspondence: nahar.kamrun@ northsouth.edu

The Phytoremediation ability of aquatic macrophyte, Azolla as potential biomass, to improve the quality of eutrophic lakes and river water of Bangladesh at lab scale were studied to remove organics, solutes and improving the physicochemical properties of water including $\mathrm{pH}, \mathrm{DO}, \mathrm{EC}, \mathrm{TDS}$, Turbidity and $\mathrm{NaCl}$ concentration. In the different eutrophic water, a $100 \%$ survival rate of the species was observed. The extensive root system of the phytoremediator improves water quality after one week as determined by a marked decrease in Turbidity, TDS, EC \& Nacl and increased in DO and $\mathrm{pH}$. DO content served as a useful indicator of water quality and increased manifolds over 7 days (one week) of treatment. The capability of the plant in removing pollutants and improving water quality was established from the study. After phytoremediation activities, the discarded energy crop biomass could be used to produce green energy because of its high growth potential.

Key words

Phytoremediation, Azolla, Water quality, Removal efficiency, Green energy

This article is is licensed under a Creative Commons Attribution-NonCommercial 4.0 International License.

Attribution-Non Commercial (CC BY-NC) license lets others remix, tweak, and build upon work non-commercially, and although the new works must also

acknowledge \& be non-commercial.

\section{INTRODUCTION}

Azolla caroliniana, known as mosquito fern, a floating aquatic macrophyte available in Bangladesh in its natural aquatic habitats. This aquatic macrophyte has been well identified for its phytoremediation ability in aquatic ecosystem. Contamination of surface water in aquatic environment has become one of the major environmental problems in developed as well as in developing countries including Bangladesh. Phytoremediators are capable of removing pollutants in greater concentrations and help to purify the eutrophic water. Phytoremediation is a plant based green technology receiving increasing attention to accumulate toxic substances in plant from the aquatic ecosystem. This green technology by using remediators are beneficial compared to conventional methods because of its low costs \& inputs including low environmental impacts and public acceptability. Aquatic green macrophytes, can not only be effectively used to remove pollutants from contaminated waters (Miretzky et al. (2004); Olguín et al. (2017); Alam and Hoque (2017); Odjegba \& Fasidi (2004); and Qin et al. (2016) and also to produce biofuels (Nahar, 2012; Nahar and Sunny, 2019) which could be produced from any biological carbon containing biomass and the most common carbon sources are photosynthetic plants (Nahar et al., 2011). Urbanization and over-population are increasingly posing serious concerns for surface waters like river, lakes and other water bodies, due to improper sewage disposal and contaminations (Bhateria and Jain 2016). Aquatic macrophytes have a high potential for phytoextraction or absorption of organics, salts, solids and metals in their tissues (Rezania et al., 2015) and purify contaminated water bodies. Bangladesh as a riverine country has great diversity of the aquatic ecosystems. The greater proportion of aquatic ecosystems of our country is represented by rivers and lakes (Nahar and Sunny, 2019). However, the aquatic ecosystems of Dhaka, the capital of Bangladesh, under tremendous anthropogenic pressures, 
over the years and their ecological status has significantly deteriorated due to water pollution occurring by different human activities. The present work provides an overview of diversity of aquatic ecosystems in the city, with their water quality status and subsequently, the remediation to these ecosystems using aquatic macrophyte at lab scale. So the present research emphasis on utilization of Azolla as a promising candidate for remediation of contaminated lakes and river water of Dhaka city and the harvested biomass to use as biofuels.

\section{Material AND Methods}

The experiment was conducted in the Laboratory, Department of Environmental Science and Management, North South University, Dhaka Bangladesh. Pollutants load of eutrophic water were determined before and after treatment by growing aquatic plant, Azolla carolianiana to evaluate the phytoremediation potential. Water samples were collected from 2 lakes and one river of Dhaka city. This study was carried out from October 6 to October 13, 2019 to explore the ability of the mentioned macrophyte as remediating agent for solid and salts removal from collected water samples.

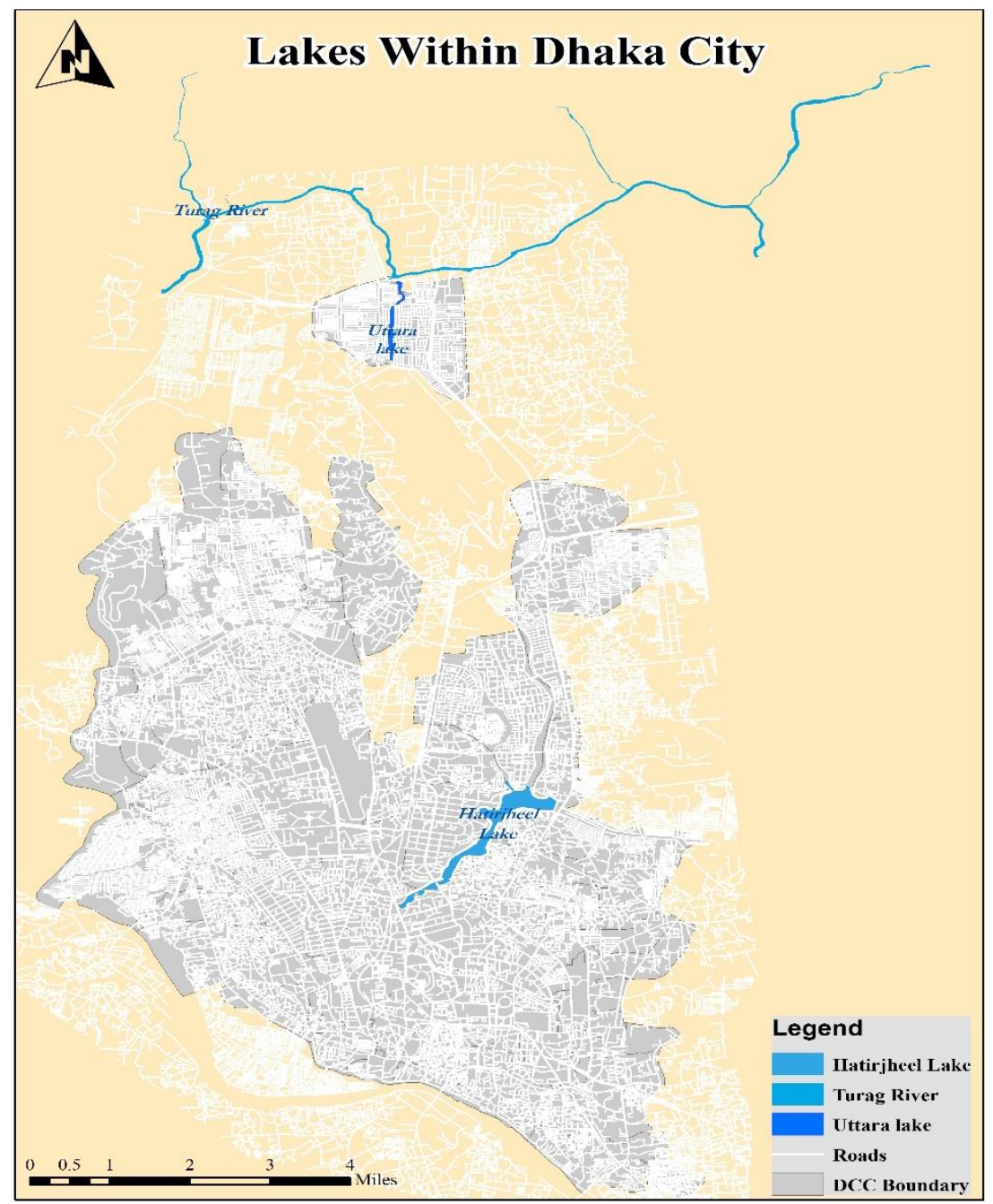

Figure 1: Lakes and River within Dhaka city from where water samples were collected

Azolla after brought to the laboratory was kept on a filter paper to remove excess water and then transferred into beaker having a capacity of one liter containing water collected from different aquatic systems. Before transferring the test plant into the container the water characteristics of the collected samples were determined by analyzing some physical and chemical parameters like Colour, TDS, EC, pH, DO, Turbidity and Nacl. Seven days after addition of phytoremediator, the water samples were re-analyses. The value before phytoremediation was indicated by initial value while the value after phytoremediation noted as final value. Thus, changing of physical and chemical properties of water samples as well as percent removal of pollutants were investigated by growing plant. A 7 days $(168 \mathrm{~h})$ experiment was performed under a controlled environment in the laboratory. 


\section{Collection of Water Samples}

In this study water samples from shallow depth were collected from Hatirjheel lake (Sample A) Uttara lake (Sample B) and Turag river (Sample C) of Dhaka City, Bangladesh (Figure 1). Samples were obtained by dipping plastic bottles at three places across the surface of each sampling site and then mixed. The mentioned water bodies accumulated wastewater from the surrounding urban community and became eutrophic.

\section{Collection of Tests Aquatic Macrophyte}

To carry out a Floating Aquatic Macrophyte based Treatment (FAMT) of eutrophic water, Azolla was selected as a test aquatic macrophyte. Azolla Caroliniana, (Kingdom: Plantae, Class: Polypodiopsida, Order: Salviniales, Family: Salviniaceae Genus: Azolla, Species: Azolla Caroliniana.) was collected from the small ornamental water pond from author's roof top garden that had no connection with domestic and industrial discharges (Figure 2).

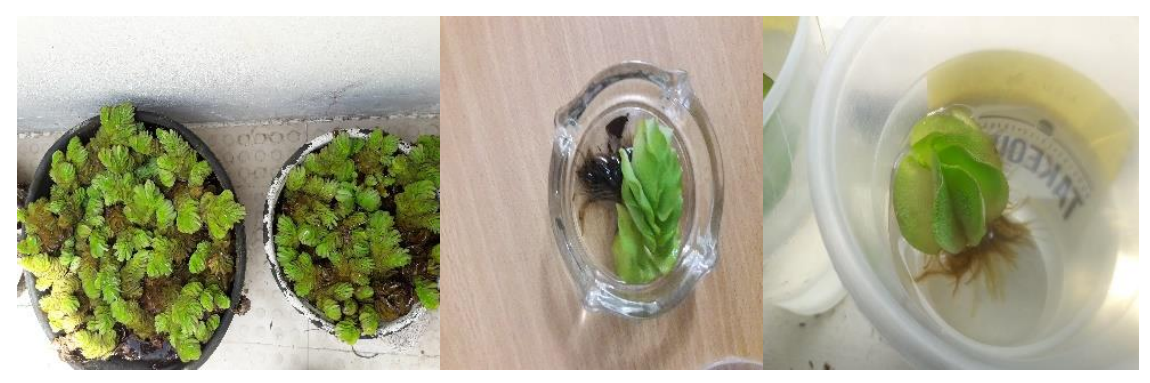

Figure 2: Collection and cultivation of water lettuce in the laboratory

The plants used for phytoremediation experiments were transported to the laboratory, rinsed with water and then placed in a container with lab tap water and placed under sunlight beside the widow of the lab for 3-5 days to let them adapt. The mentioned macrophyte used in this study were cultured in the laboratory by placing in beakers $(1 \mathrm{~L})$ with the eutrophic waters collected from the sampling sites and were kept at temperature $25^{\circ} \mathrm{C}$ under $14 / 10 \mathrm{~h} \mathrm{light}$ and dark photoperiod in beaker.

\section{INSTRUMENTATION}

The $\mathrm{pH}$ of water samples monitored using a $\mathrm{pH}$ meter (Griffin $\mathrm{pH}$ meter, Model No. 40) and a glass electrode, while the Dissolved Oxygen was determined using Hanna Instruments HI 9143- Dissolved Oxygen Meter, Portugal (DO meter). The DRT-100B, HF Scientific Inc., USA was used to measure the turbidity, whereas TDS, $\mathrm{EC}$ and $\mathrm{NaCl}$ ( 3 in 1 ) were measured by durable and portable TDS/EC/ NaCl meter (Hanna Instruments HI 9835 Model, USA).

The treatments were evaluated by measuring the physiochemical parameters of collected samples just after bringing to the laboratory and after addition of macrophyte also were taken after one week (168 hours). So the characteristics of the eutrophic water samples were determined before and after the end of the experiment and the rate of reduction or increment of any was recorded on the experiment lasted for one week.

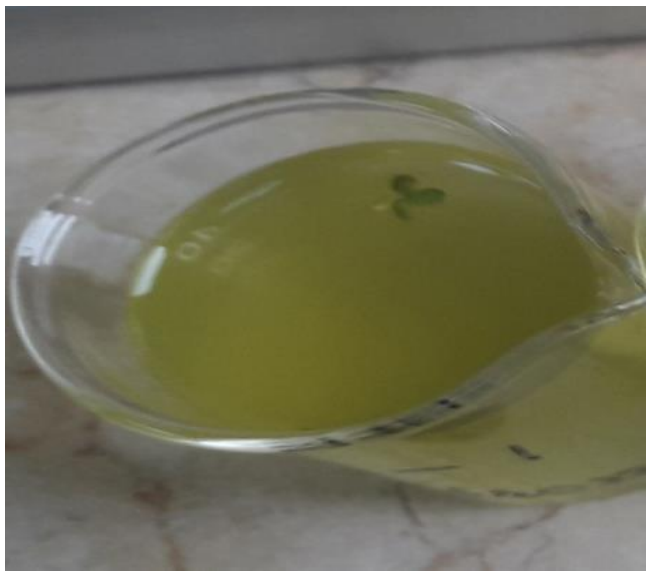

a

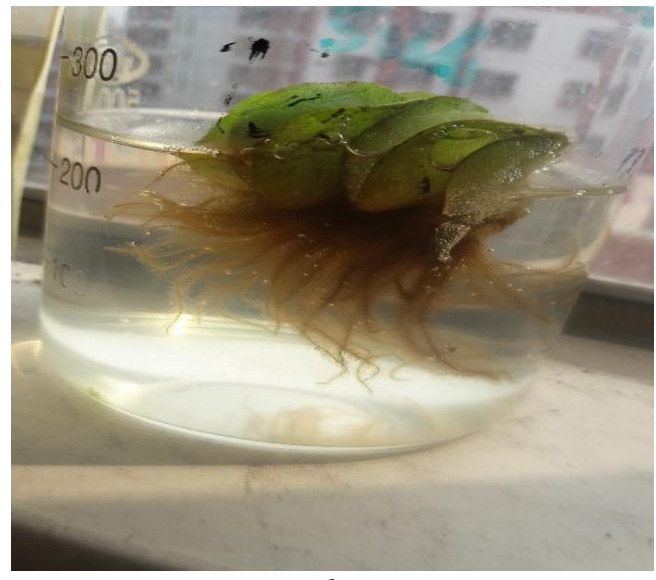

b

Figure 3: Water Quality before and after remediation. a. Water sample before remediation b. Improvement of water quality after 168 hours (7 days) of phytoremediation 


\section{Results AND Discussion}

The results of phytoremediation effectiveness by Azolla, tested in laboratory revealed that the mentioned macrophyte at different samples was capable of decreasing or increasing all tested indicators of water quality to levels that permit the use of the purified water for different uses except as drinking water. The physiochemical parameters of Lake waters (Sample A and B) and River water (Sample C) before and after treatment are presented in Figures (4, 5 \& 6). Also the Percentage Removal Efficiencies (PRE) in 3 culture samples after 168 hours of treatment are presented in Table 1 . The purification process was monitored by measuring different water parameters are showed in graphs $(4,5 \& 6)$. Initially, the water color in all samples was light greenish brown. After treatment, water looked relatively more transparent than the initially collected water (Figure 3).

Result revealed Highest improvement on 7th day of experiment, at Hatirjeel lake (sample A) followed by Uttara lake (sample B) and Turag river (sample C). The result presented in Figures 4-6, showed that $\mathrm{pH}$ was increased in all the aqueous cultures. Although TDS was best reduced at A and then C compared to sample B while DO was best increased in sample A and B if compared to sample C.

In the present study, considerable \% improvements of cultures with the treated phytoremediator were observed in all the parameters. Reduction of turbidity for the 3 water samples were $95 \%, 75 \%$ and $67 \%$ at Hatirjheel Lake, Turag River and Uttara Lake, respectively (Tables 1).

The results also showed that the percent increment of DO was highest at Hatirjheel Lake (1031\%) followed by Uttara lake $(958 \%)$, and Turag river (20\%). The other parameters like percent reduction of EC was also found highest at Hatirjheel Lake $(21 \%)$ followed by Turag river $(10 \%)$, and the lowest at Uttara lake (6\%). Same as EC, the TDS reduction was found more in Hatirjheel Lake (21\%), intermediate in Turag river $(10 \%)$ and extremely lowest in Uttara lake (5\%) which was less polluted than the other 2 entities. In case of $\mathrm{NaCl}$ contents. Highest reduction was found at Uttara lake $(25 \%), 2^{\text {nd }}$ and $3^{\text {rd }}$ position were occupied by Hatirjheel Lake (21\%) and Turag river (17\%), respectively.

Although, the $\mathrm{pH}$ values in all the cultures before phytoremediation were below the neutral level and after treatment, they all maintained the required levels in between (7.2-7.4), figure 4-6. In the experiment $\%$ increment in $\mathrm{pH}$ level was highest at Hatirjheel Lake (29\%) followed by Turag river (24\%) and .Uttara lake (12\%) (Table 1).

So the Azolla attained the highest percentage removal at the Hatirjheel Lake with a maximum value of approximately $21 \%$ (EC), $21 \%$ (TDS) and $21 \%(\mathrm{NaCl})$ as second highest removal compared to initial value (after $168 \mathrm{~h}$ of culture) with highest increment in $1031 \%(\mathrm{DO})$ and $29 \%(\mathrm{pH})$.

The results revealed Azolla as a potential macrophyte to absorb pollutants from contaminated water, preferably accumulating in their roots, demonstrating that the plant at different cultures are capable to absorb large quantities of salts, dissolved solids etc These results confirm the findings of Rodrigues et al. (2017 \& 2020), Rezania et al. (2015), Gupta and Roy (2012), Galal and Forhat (2015); Kumar et al. (2019); and Nahar and Sunny (2019), who observed that root system of Macrophytes absorb large quantities of solutes and metals from the contaminated water. Figures 4, 5 \& 6 shows physical and chemical characteristics of water before and after treatment cultures with Azolla for Sample $\mathrm{A}, \mathrm{B}$ and $\mathrm{C}$.
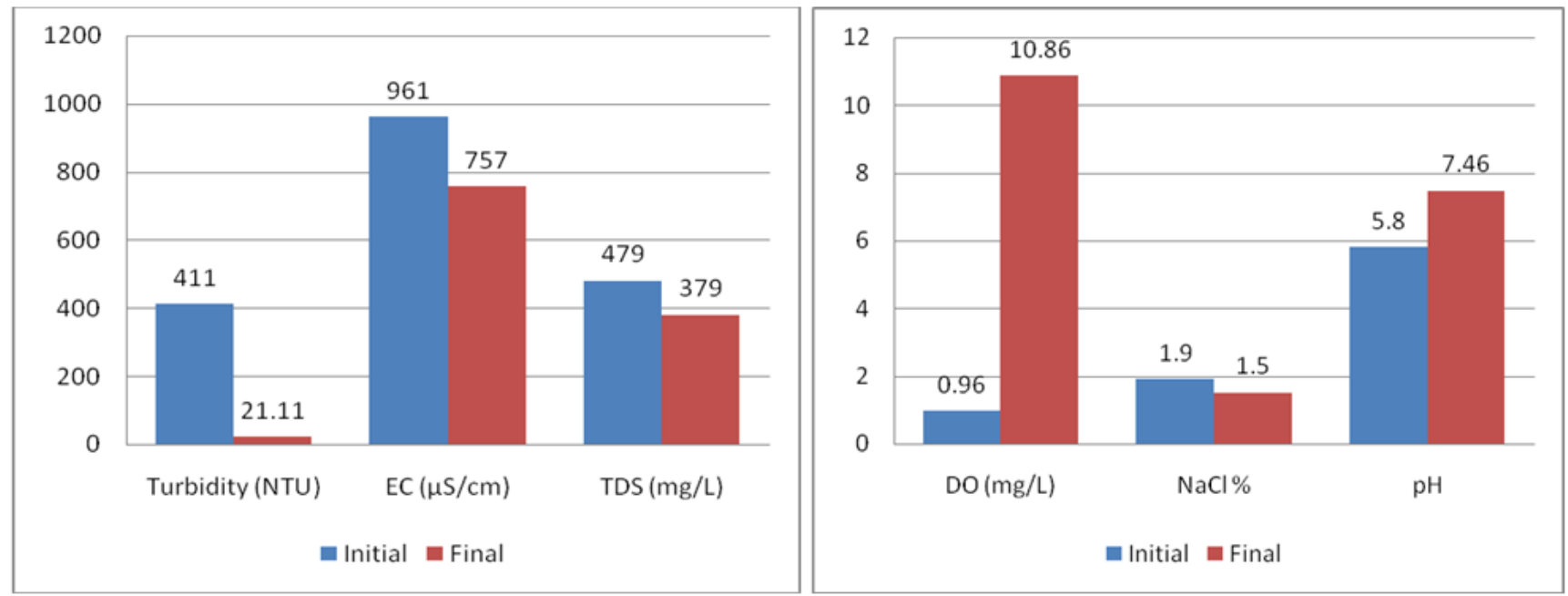

Figure 4: Hatiriheel Lake (Sample A) 


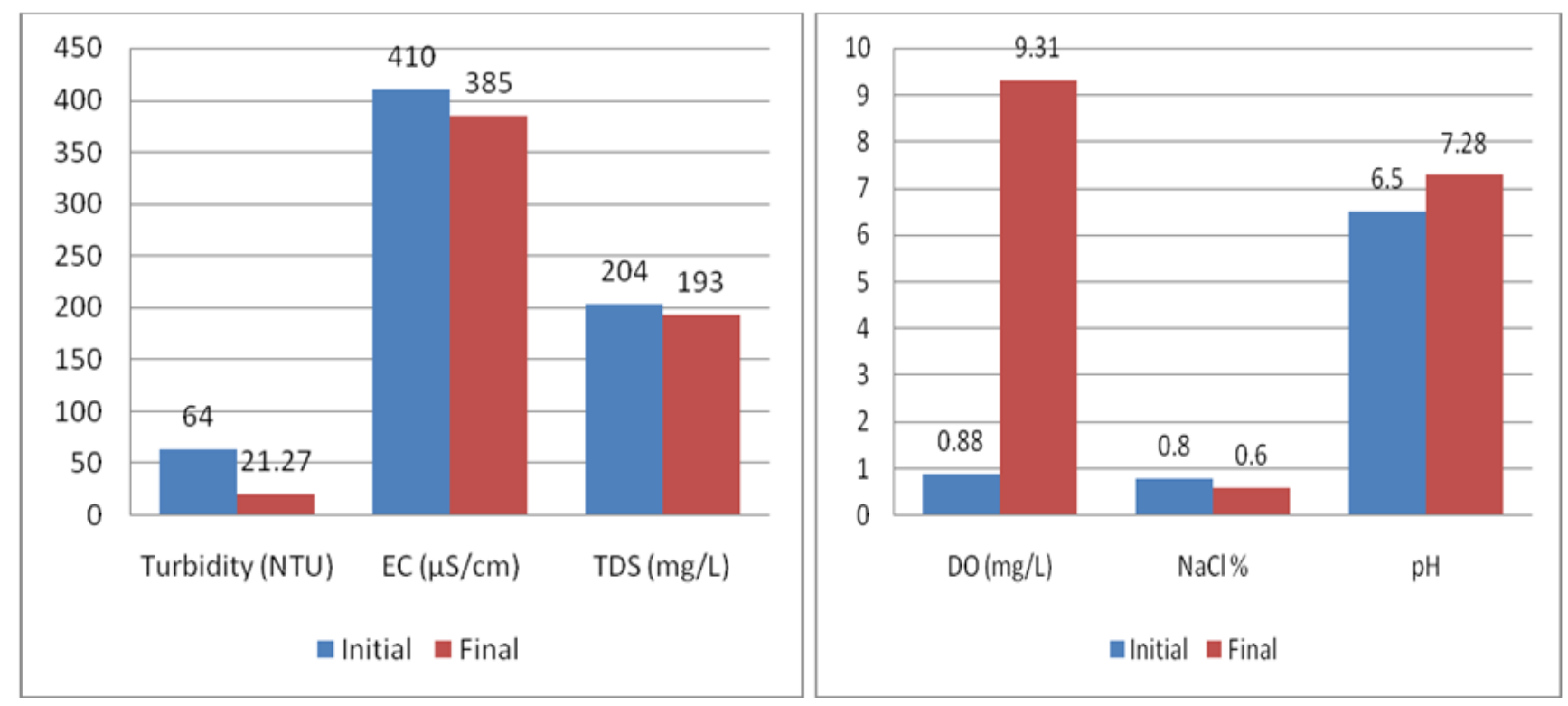

Figure 5: Uttara Lake (Sample B)
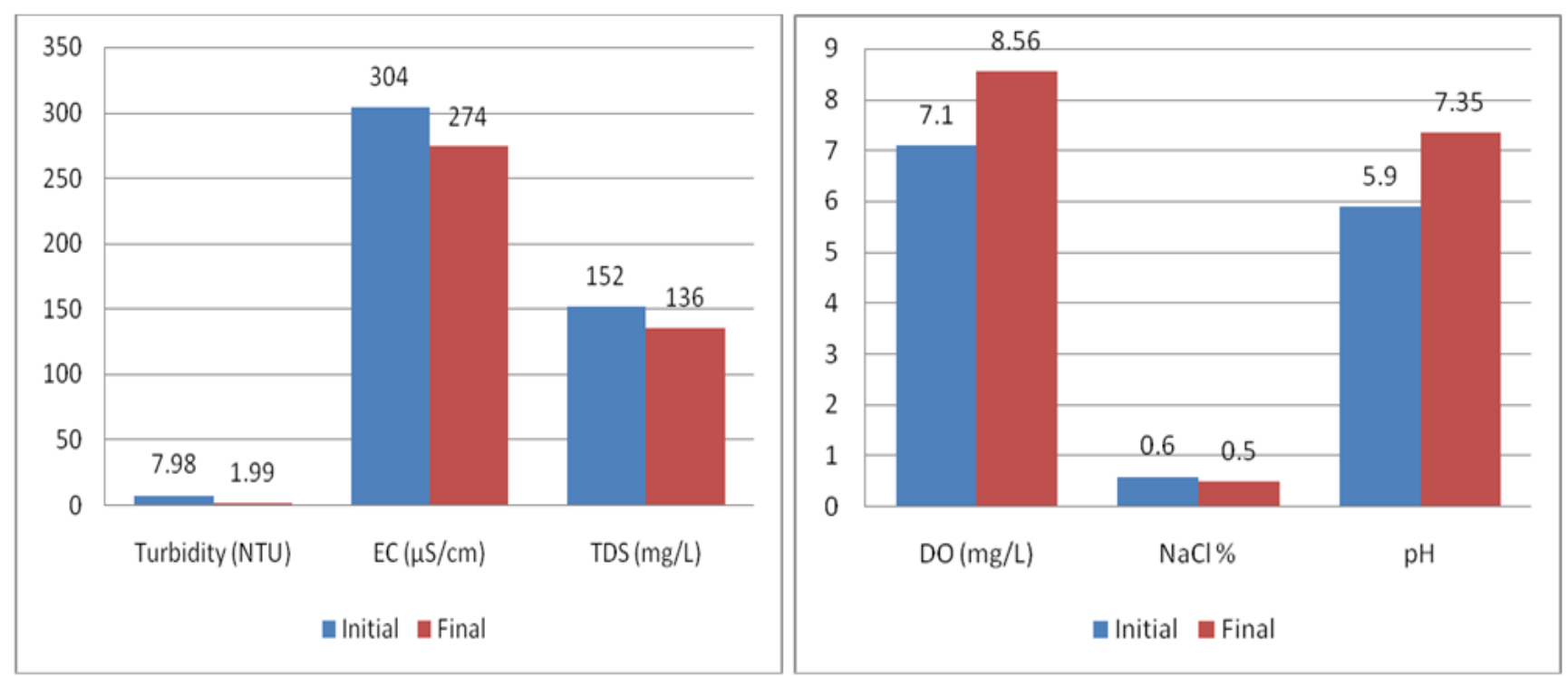

Figure 6: Turag River (Sample C)

So Aquatic macrophyte treatment system (AMTS) facilitates removal of dissolved solids, salts etc by uptake mechanism. Also here the change of water $\mathrm{pH}$ were observed in all treatments, presented in Figures $(4,5 \& 6)$. Uptake of carbonate during algal photosynthesis might be responsible for increasing $\mathrm{pH}$. Maximum amount of $\mathrm{pH}$ increased in Hatirjheel lake followed by Turag river and slightly in Uttara lake. In this study the highest percent reductions of EC of was also found in Hatirjheel followed by Turag river and lowest by Uttara river.

Table 1: Mean change (reduction shows negative \%, while increment shows positive \%) of physical and chemical parameters for samples A, B and C

\begin{tabular}{ccccc}
\hline Serial No & Water quality parameters & Sample A & Sample B & Sample C \\
\hline 1 & $\mathrm{pH}$ & $29 \%$ & $12 \%$ & $24 \%$ \\
2 & $\mathrm{TDS}\left(\mathrm{mg} \mathrm{L}^{-1}\right)$ & $-21 \%$ & $-5 \%$ & $-10 \%$ \\
3 & $\mathrm{DO}\left(\mathrm{mg} \mathrm{L}^{-1)}\right.$ & $1031 \%$ & $958 \%$ & $20 \%$ \\
4 & $\mathrm{EC}(\mu \mathrm{SS} / \mathrm{cm})$ & $-21 \%$ & $-6 \%$ & $-10 \%$ \\
5 & $\mathrm{NaCl}(\%)$ & $-21 \%$ & $-25 \%$ & $-17 \%$ \\
6 & Turbidity (NTU) & $-95 \%$ & $-67 \%$ & $-75 \%$ \\
\hline
\end{tabular}


The changes in Dissolved oxygen (DO) of water are presented in Figures 4, 5 \& 6. DO increased in cultures of Hatirjheel Lake, with the intermediate in Uttara Lake and the minimum in Turag. As the Hatirjheel Lake was more polluted, there may be higher photosynthetic activities by phytoplankton, for which the highest amount of DO level was recorded there. In this experiment the lower amounts of $\mathrm{DO}$ with the plant in cultures could be explained by reduced diffusion of oxygen into the water due to higher rates of respiration in roots and oxygen uptake by microorganisms present in sample culture. So differences in DO levels among the plant cultures were due to their different rate of oxygen exchange from aerial tissue into the root zone (Reeta and Ann, 2004). On average, water turbidity was reduced and was highest in Hatirjheel followed by Turag River and lowest in Uttara Lake and in 3 cultures as compared with the one like Hatirjheel, was the highest removal of tubidity which is the transparency of water.

The improvement of water quality requires simultaneous removal of excess nutrients, salts, TDS, along with adjusting pH, DO, etc. The implication of our finding is in consistent with Reyes \& Santos (2019), Nabi et al. (2016); Nassouhi et al. (2018); Qin et al. (2016); Rezania et al. (2015); Zimmel et al. (2006); and Ansari et al. (2020), who postulates that aquatic macrophytes considered as important tools in phytotechnologies and can be used as an effective bio-agent for treating contaminants in aquatic environment. In the present experiment, the water qualities in all water samples were improved, as evidenced by decreases in Total Dissolved solids, Sodium chloride content and Electrical conductivity. Also water turbidity was decreased by more than $60 \%$ in all the cases in our experiment.

Azolla increased average $\mathrm{DO}$ and $\mathrm{pH}$ concentrations in all the treatment cultures. Our result also confirm the findings of Mahmood et al. (2005); Alam and Hoque (2017); Lu et al. (2010); Dipu et al. (2011); and Gaballah et al. (2019), who observed DO and $\mathrm{pH}$ levels improved by aquatic macrophytes and also improving the physiochemical properties of eutrophic water. The improvement in $\mathrm{pH}$ occurred due to absorption of salts, solids, nutrients etc. by plant and also by photosynthetic activities. Our findings also show that Azolla is a suitable and potential candidate for phytoremediation of contaminated surface water ecosystem in tropical areas and consistent with the findings of Galal et al. 2018; Awuah et al., 2004, those who used aquatic plants in their study for phytoremediation. The mentioned macrophyte in our experiment exhibited a higher solid and salts removal efficiency, because of its strong roots with higher absorption capacity, acts as the most efficient phytoremediator for the removal of selected solids and salts as followed by results from analysis of Gijzen and Kondker (1997) and Ugya et al. (2015b); Nabi et al. (2016); Carolin et al. (2017); Galal et al. (2018); and Leung et al. (2017) as the plant captured the pollutants by the roots and rapidly transported to the upper vegetative body parts acts as a sink for the contaminants. The results of the present study revealed reduction of TDS, EC and turbidity was higher in Sample A which was more eutrophied compared to other 2 entities. The maximum purification by growth of the mentioned macrophyte achieved at most polluted water of Hatirjheel Lake as sample A.

Also after using the plant as phytoremediator, the harvested biomass could be used to produce biofuels as sources of clean energy. Anaerobic fermentation of Azolla produces methane gas which can be utilized as clean fuel. The remaining sludge can be used as a good source of organic fertilizer. Besides, liquid fuel could also be produced from Azolla as bio-oil. It helps to reduces greenhouse gas emissions because biofuels produced by Azolla is a by-product of its sequestration of atmospheric $\mathrm{CO}_{2}$. It can also be used to produce hydrogen, a nonpolluting, high-energy fuel. Overall, the results of the present study showed that Azolla could be considered as a potential aquatic macrophyte for effective phytoremediation of water from different lakes and river in Dhaka city. It is also evident that the mentioned macrophyte is good tolerant to pollutants, without showing any visible symptom of damage, toxicity or reduction in growth. Besides, the pungent odor of the initially collected raw water gradually disappeared during the remediation period while the greenish brown color turned almost colorless in the final water samples.

\section{CONCLUSION}

Azolla as an aquatic macrophyte can remediate eutrophic waters in city by improving the physical and chemical properties of water. Based on our results we can say that it can be used as a biological tool in a developing country like Bangladesh for effective treatment of polluted water before being dumped in the ecosystems. Using the floating macrophyte in eutrophic ecosystem is a cost-effective and clean up technique for remediation of contaminated area thus can maintain their sustainability. In conclusion, Azolla not only consider suitable candidate for effective phytoremediation of polluted water bodies, the harvested plant biomass can also be used to produce Biofuels.

\section{ACKNOWLEDGEMENTS}

This research was supported by the Environmental Laboratory, Department of Environmental Science and Management, North South University, Dhaka, Bangladesh. 


\section{REFERENCES}

Alam, A. R. and Hoque, S. (2017). Phytoremediation of industrial wastewater by culturing aquatic macrophytes Trapa natans L. and Sahinic cucullat Roxb. Jahangirnagar University Journal of Biological Sciences 6(2), 19 - 27.

Ansari, A. A., Naeem, M., Gill, S. S.., AlZuaibr, F. M. (2020). Phytoremediation of contaminated waters: An eco-friendly technology based on aquatic macrophytes application. Egyptian Journal of Aquatic Research. https://doi.org/10.1016/j.ejar.2020.03.002

Awuah, E., Oppong-Peprah, M., Lubberding, H. J., \& Gijzen, H. J. (2004). Comparative performance studies of water lettuce, duckweed, and algal-based stabilization ponds using low-strength sewage. Journal of Toxicology and Environmental Health, Part A, 67(20-22), 1727-1739.

Bhateria, R., \& Jain, D. (2016). Water quality assessment of lake water: a review. Sustainable Water Resources Management, 2(2), 161173.

Carolin, C. F., Kumar, P. S., Saravanan, A., Joshiba, G. J., \& Naushad, M. (2017). Efficient techniques for the removal of toxic heavy metals from aquatic environment: A review. Journal of environmental chemical engineering, 5(3), 2782-2799.

Dipu, S., Kumar, A. A and Thanga, V. S. G. (2011). Phytoremediation of dairy effluent by constructed wetland technology. Environmentalist, 31: 263-278.

Gaballah. M. S. Ismail, K., Beltagy, A., Zein Eldin, A. M., Ismail, M. M. (2019). Wastewater Treatment Potential of Water Lettuce (Pistia stratiotes) with Modified Engineering Design. Journal of Water Chemistry and Technology, 41(30), 197-205.

Galal, T. M. and Farahat, E. A. (2015). The invasive macrophyte Pistia stratiotes L. as a bioindicator for water pollution in Lake Mariut, Egypt. Environ Monit Assess. 187(11)701. https://doi.org/10.1007/s10661-015-4941-4

Galal, T. M., Eid, E. M., Dakhil, M. A., \& Hassan, L. M. (2018). Bioaccumulation and rhizofiltration potential of Pistia stratiotes L. for mitigating water pollution in the Egyptian wetlands. International journal of phytoremediation, 20(5), 440-447.

Gijzen H. and Kondker M. (1997). An Overview of the Ecology, Physiology, Cultivation and Application of Duckweed in Caption Report. Annex-1, Literature Review. Duckweed Research Project (DWRP). Dhaka, Bangladesh.

Gupta, P. Roy, S. \& Mahindrakar, A. B. (2012). Treatment of Water Using Water Hyacinth, Water Lettuce and Vetiver Grass - A Review. Resources and Environment, 2(5), 202-215.

Kumar. V., Singh, J., Saini, A., Kumar, P. (2019). Phytoremediation of copper, iron and mercury from aqueous solution by water lettuce (Pistia stratiotes L.). Environmental Sustainability, 2(1), 55-65. https://doi.org/10.1007/s42398-019-00050-8

Leung, H. M., Duzgoren-Aydin, N. S., Au, C. K., Krupanidhi, S., Fung, K. Y., Cheung, K. C., \& Tsui, M. T. K. (2017). Monitoring and assessment of heavy metal contamination in a constructed wetland in Shaoguan (Guangdong Province, China): bioaccumulation of $\mathrm{Pb}, \mathrm{Zn}, \mathrm{Cu}$ and $\mathrm{Cd}$ in aquatic and terrestrial components. Environmental science and pollution research, 24(10), 9079-9088.

Lu, Q., He, Z. L., Graetz, D. A., Stoffella, P. J., \& Yang, X. (2010). Phytoremediation to remove nutrients and improve eutrophic stormwaters using water lettuce (Pistia stratiotes L.). Environmental Science and Pollution Research, 17(1), 84-96.

Mahmood, Q., Zheng, P., Islam, E., Hayat, y., Hassan, M.J., Jilani, G. and Jin, R.C. (2005) Labscale studies on water hyacinth (Eicchorniacrassipesmart solms) for biotreatment oftextile waste water. Caspian J. Env.Sci. 3(2), 83-88.

Miretzky, P., Saralegui, A., \& Cirelli, A. F. (2004). Aquatic macrophytes potential for the simultaneous removal of heavy metals (Buenos Aires, Argentina). Chemosphere, 57(8), 997-1005.

Nabi, A., Alam, K. M. R., Hoque, S. (2016). Treatment of wastewater with free floating quaticmacrophyte - Eichhornia crassipes. Jahangirnagar University Environ. Bull. 5, 1-9.

Nahar, K. and Sunny, S. (2019). Duckweed based clean energy production dynamics (Ethanol and Biogas) and Phytoremediation potential in Bangladesh. Springer nature, Modeling Earth System and Environment, 5(4), 1-11. https://doi.org/10.1007/s40808$\underline{019-00659-\mathrm{y}}$

Nahar, K., Sunny, S. A., \& Shazi, S. S. (2011). Land use requirement and urban growth implications for the production of biofuel in Bangladesh. Canadian Journal on Scientific and Industrial Research, 2(6), 195-208.

Nahar. K. (2012). Biogas Production from Water Hyacinth (Eichhornia Crassipes). Asian Journal of Applied Science and Engineering, 1(1): $9-13$

Nassouhi, D., Ergonal, M. B., Fikirdesici, S., Karacakaya, P., Atasagun, S. (2018). The use of some submersed and free floating aquatic macrophytes in the bioremediation of heavy metal pollution. Journal of Egirdir Fisheries Faculty SDU- JEFE 14 (2), $148-165$

Odjegba, V. J., \& Fasidi, I. O. (2004). Accumulation of trace elements by Pistia stratiotes: implications for phytoremediation. Ecotoxicology, 13(7), 637-646.

Olguín, E. J., García-López, D. A., González-Portela, R. E., \& Sánchez-Galván, G. (2017). Year-round phytofiltration lagoon assessment using Pistia stratiotes within a pilot-plant scale biorefinery. Science of the Total Environment, 592, 326-333. 
Qin, H., Zhang, Z., Liu, M., Liu, H., Wang, Y., Wen, X., \& Yan, S. (2016). Site test of phytoremediation of an open pond contaminated with domestic sewage using water hyacinth and water lettuce. Ecological engineering, 95, 753-762.

Reeta, D. S., and Ann, C. W. (2004). Nutrient removal by floating aquatic macrophytes cultured in anaerobically digested flushed dairy manure wastewater. Ecol. Eng. 22, $27-42$.

Reyes, A. T., and Santos, M. K. M. (2019). Phytoremediation potential of Water Hyacinth (Eichhornia crassipes) in tanks with high organic matter. Int J. fish Aquat Stud 7(6), 107-109.

Rezania, S., Ponraj, M., Talaiekhozani, A., Mohamad, S. E., Din, M. F. M., Taib, S. M., \& Sairan, F. M. (2015). Perspectives of phytoremediation using water hyacinth for removal of heavy metals, organic and inorganic pollutants in wastewater. Journal of environmental management, 163, 125-133.

Rodrigues, A. C. D., do Amaral Sobrinho, N. M. B., dos Santos, F. S., dos Santos, A. M., Pereira, A. C. C., \& Lima, E. S. A. (2017). Biosorption of toxic metals by water lettuce (Pistia stratiotes) biomass. Water, Air, E Soil Pollution, 228(4), 156.

Rodrigues, A. C. D., Rocha, M. V. D. C., Lima, E. S. A., Pinho, C. F. D., Santos, A. M. D., Santos, F. S. D., \& Amaral Sobrinho, N. M. B. D. (2020). Potential of water lettuce (Pistia stratiotes L.) for phytoremediation: physiological responses and kinetics of zinc uptake. International Journal of Phytoremediation, 1-9.

Ugya, A. Y., I. M., Toma, and Abba A. (2015b) Comparative Studies on the Efficiency of Lemna minor L., Eicchorniacrassipes and Pistia stratiotes in the phytoremediation of Refinery Waste Water. Sciences World Journal, 10(3).

Zimmel, Y., Kizhener, F., and Malkovskaja, A. (2006). Application of Eichhornia crassipes and Pistia stratiotes for treatment of urban sewage in Israel. J. Environ. Manag. 81(4), 420-428. 